\title{
Portuguese Labour Market Governance in Comparative Perspective
}

\author{
Alexandre Afonso, Leiden University
}

\begin{abstract}
This chapter analyses the core characteristics of labour market governance in Portugal in a comparative perspective, analyzing the interplay of public and private regulation in the setting of wages and employment conditions. The chapter describes the main characteristics of the Portuguese employment model within the European context and how it departs from other Southern European countries, notably when it comes to female and low-skilled employment. The chapter argues that the power relationships that emerged out of the transition to democracy favoured a more liberal employment regime than in Spain, resulting in a lower threshold of unemployment but also higher income inequalities and lower wage protections. The models have tended to converge in recent years, and income inequality in Portugal has diminished. The chapter highlights the high level of female employment since the 1960s, a characteristic that departs significantly from other Southern European countries. It is explained by specific contextual factors, notably the legacy of the colonial war and high rates of emigration.
\end{abstract}

Keywords: Portugal, labour market policies, collective bargaining, employment protection, employment, gender

Words: 6557

\section{Introduction}

Portugal is often bundled within the broader "Southern" or "Mediterranean" model of welfare and employment when it comes to the governance of its labour market (Ferrera 1996; Zartaloudis and Kornelakis 2017). In many ways, Portuguese labour market governance indeed shares many characteristics with Spain, Italy or Greece: high levels of segmentation between "insiders" and "outsiders", relatively high levels of inequality, the large size of the informal sector, and a reliance on the state to regulate wages and employment rather than on social partners alone, as in Scandinavia. However, it has also departed in significant ways from comparable countries on a number of indicators. While typical shortcomings of Southern European employments models have been the low levels of employment of women and the lowskilled, owing to a catholic tradition and what was often perceived as too restrictive employment protection, Portugal has done remarkably well in the employment of these groups. In 2019 Portugal had the highest rate of women employed in relation to the population in Southern Europe: $75 \%$ of Portuguese women between 25 and 64 were employed (on par with the Netherlands or Denmark), compared to $64 \%$ in Spain and $56 \%$ in Italy (OECD 2020b). 
Similarly, $70 \%$ of Portuguese individuals with below upper secondary education were employed (one of the highest rates in the OECD) compared to 58\% in Spain and 52\% in Italy.

In comparative terms, the Portuguese model of welfare and employment has been described as a "liberal" variant contrasting with the more "protective" Spanish model (Watson $2015,1)$. While Spain had higher levels of social and wage protection but also a much higher threshold of unemployment, Portugal, at least in the decades that followed democratization, displayed lower unemployment but also lower wage protection, as well as higher levels of inequality and poverty. The models have converged in the recent decade, with inequality increasing to a greater extent in Spain than in Portugal (Perez and Matsaganis 2019). However, notable differences in unemployment rates have persisted up to now (Bover, García-Perea, and Portugal 2000). For the last 30 years, the average unemployment rate in Portugal has been $8.5 \%$, compared with $16.5 \%$ in Spain. At the same time, in 2018 Portuguese median hourly earnings only amounted to $53 \%$ of Spanish ones.

In this chapter, I outline the main characteristics of the Portuguese model of labour market governance across three dimensions: labour market policies, collective bargaining and labour market outcomes in a comparative perspective. I focus on the development and change of institutions which regulate employment relations: wages, working conditions, working hours, unemployment protection and wage-setting institutions. I first review the characteristics and development of public policies organizing the labour market (employment protection, active labour market policies, skills and education), then outline the main dimensions of the system of industrial relations, and conclude with how these institutions have shaped a number of outcomes such as unemployment, employment rates and inequality. The chapter traces developments from the advent of democracy in 1974 to the movement of liberalization that has taken place in the wake of the Eurozone crisis and up to the support measures implemented during the corona pandemic. The chapter is comparative in nature, highlighting how the Portuguese case resembles but also diverges from other comparable European countries, especially in the Mediterranean or "Southern" cluster composed of Spain, Italy, and Greece (Regini, Pavolini, and Burroni 2021).

\section{Context and Emergence of the Portuguese Labor Market Regime}

A central factor in the emergence of welfare states and labour market regulations in Europe from the late $19^{\text {th }}$ century onwards has been the capacity of organized labour to mobilise and 
pressure employers and the state to regulate employment relationships (Korpi 1983). In the most developed welfare states or "coordinated economies" (Hall and Soskice 2001), labour is extensively "de-comodified", that is, an extensive set of limits are introduced in the ability of employers to use labour as a pure commodity, notably through restrictions on the employment of certain types of individuals (e.g children), limits on the ability to fire them, and income alternatives outside the market (unemployment insurance or other benefits) (Esping-Andersen 1990, 21).

Just as other late industrialisers such as Spain, Italy or Greece, Portugal was a poor, agricultural society with no meaningful industrial working class at the turn of the $20^{\text {th }}$ century. As such, it did not display the conditions that enabled the emergence of expansive welfare states and cooperative industrial relations that emerged in core European countries in that period. Hence, while elsewhere trade unions were starting to become forces to be reckoned with around 1900, Spain and Portugal "stood completely outside of this pattern of labour political progress" (Crouch 1993, 94). If the first Portuguese trade unions emerged and were legalized in 1891, the labour movement remained weak. When it did gain some clout in the early twentieth century, it was mostly influenced by radical tendencies (e.g anarcho-syndicalism, then Communism in the 1920s) which ruled out any form of class collaboration (Barreto and Naumann 1998, 9). Adversarial industrial relations, fostered by insurgent labour, ideological divisions within the union movement and a repressive state unwilling to share power have been a common feature of industrial relations in Southern Europe. In the Portuguese context, the influence of Communism forged in that period would persist within the trade union movement even after the fall of the dictatorship.

Under Antonio de Oliveira Salzar's corporatist Estado Novo (1933-1974), both employer and trade union organisations became appendixes of the state and were tightly controlled by the regime. Wages, prices and industrial decisions could be subordinated to the regime's economic policy objectives. On the one hand, the repressive nature of the regime functioned as a tool of wage restraint depriving labour from its power resources: strikes were outlawed and repressed, autonomous unions were abolished, and the legislature was controlled by the regime. One indivator of the weak power of labour was the delay with which Portugal adopted ILO labour conventions regarding safety at work, minimum wages or child labour. For instance, while ILO convention 59 of 1937 defined 15 as the minimum working age, Portugal only ratified it 33 years later. Before 1970, Portuguese legislation allowed 12-year-olds to work (ILO 2019, 66). If we refer back to the idea of de-commodification mentioned above, this shows how commodified labour still was. 
On the other hand, the regime also constrained capital's industrial decisions via an elaborate system of licensing: the relocation of plants or investments in machinery required government approval (Baklanoff 1992, 4). Nevertheless, some industrial conflict never vanished, and occasional wildcat strikes were repressed (Barreto and Naumann 1998, 13). In spite of their lack of autonomy, trade unions managed to achieve some improvement for their members. This took place against the background of favourable market developments. In the 1960s economic growth accelerated, and the labour shortage created by the colonial war started in 1961, coupled with large-scale emigration, created the conditions for substantial wage increases and, as will be emphasized later, the entry of large numbers of women in the workforce. On the eve of the 1974 revolution, $36 \%$ of the workforce was a union member (Barreto and Naumann 1998, 11).

The market-friendly characteristics of the employment model that emerged out of the 1974 revolution were shaped by the nature of the transition to democracy, and especially by the divisions within left-wing forces and the trade union movement. Paradoxically, it was the strong position of the radical left in Portugal which, according to Watson $(2015,44)$, fostered a more liberal model of employment regulation than in Spain. Unlike Spain, the Communist party was a significant political force during the Portuguese transition to democracy. Its role was especially important insofar as it managed to gain control of the structures of union representation in the aftermath of the revolution, notably through the largest union CGTP (Watson 2015, 63-64). Trade union density in Portugal hovered around 60\%, or twice the Spanish rate. Within the political sphere, the Communist party remained a significant electoral force, hovering above $15 \%$, while it wasn't really a force to be reckoned with in Spain.

Far from establishing labour dominance, this balance of power resulted in an intra-left stalemate. Communist control of the labour movement precluded meaningful political exchange with employers and the state. The Communists' uncompromising positions - both in the sphere of industrial relations and the political arena - created incentives for the centre-left (the Socialist party) to coalesce with the right-of-centre PSD and seek to undermine the PCP's power resources instead, notably by eroding the power base of the CGTP. Hence, in spite of its stronger position than in Spain, the divisions within the Portuguese left contributed to create a much more liberal model than in Spain, with lower levels of protection and a more commodified labour market. This could be observed in employment protection, unemployment insurance, as well as in the collective bargaining framework. 


\section{Labour Market Policies}

There are three central public policy instruments that have been used to steer the labour market: employment protection, minimum wages, and unemployment insurance. Here, I analyse their characteristics and evolution in turn, putting them in the political context outlined above.

Employment protection. A characteristic commonly assumed to hamper employment performance in Southern Europe has been rigid employment protection. In systems with low fiscal capacity and gaps in social protection, protecting jobs by making dismissals more difficult has appeared as an alternative to protecting individuals outside the labour market though a generous social safety net. In the Portuguese context, employment protection has often been presented as a problem, notably in the programme of reforms implemented in the wake of the Eurozone crisis from 2011 onwards. In fact, following the widely used OECD Employment Protection Legislation indicator, up to the 2010s, Portugal had the most restrictive employment protection legislation in the OECD. However, this aggregated indicator is misleading if one looks at the actual functioning of litigation for fair and unfair dismissals, as well as issues of enforcement (Watson 2015, 8). In many respects, employment protection in Portugal has been less constraining for employers than in Spain.

First, although penalties for fair dismissals were indeed higher in Portugal, there were in fact more incentives for workers in Spain to appeal in court claiming their dismissal was unfair. In Portugal, the only benefit of claiming unfair dismissal was reinstatement, which in practice limited the number of appeals. In Spain, by contrast, when courts declared a dismissal unfair, this would considerably increase severance payments. Spanish companies were often unable to provide justification for the cause of dismissals, and in $199680 \%$ of rulings would be in favour of employees. To avoid this, Spanish firms would routinely make legal settlements with workers to avoid litigation, shelling out payments close to the maximum for unfair dismissal (Bover, García-Perea, and Portugal 2000, 385). Second, the other issue had to do with enforcement. Unlike any other other European country, Portuguese legislation tolerated the delayed payment of wages. Rather than laying off workers or claiming bankruptcy, firms were allowed to delay the payment of wages up to over a year. Employees who had not been paid and sought employment elsewhere were considered to have voluntarily separated, and were not entitled to unemployment protection or severance pay (Watson 2015, 9). In practice, dismissals were therefore more costly in Spain than in Portugal in spite of formally higher cost in Portugal.

In spite of these already liberal features in practice, employment protection was extensively reduced in the 2010s in the wake of the Eurozone crisis, under considerable external 
pressure. When Portugal faced a potential solvency crisis as yields on its debt skyrocketed in 2010, it agreed to a bailout package by a Troika of financial institutions (European Central Bank, European Commission, International Monetary Fund) in exchange of which it committed to an extensive programme of economic and social reforms aimed at restoring competitivness (Afonso 2019; Branco and Cardoso 2020; Moury and Standring 2017). The Portuguese economy had been in a phase of stagnation since the early 2000s, characterized by low growth a a deterioration of the trade balance (Amaral 2010, 44). Within a common currency regime, the only envisaged channel to restore competitiveness was internal devaluation, namely a downward adjustment of wages and prices. A deregulation of employment protection was believed to have a significant role to play in this process by enabling a quicker adjustment of wages to market conditions and higher unemployment. As such, dismissals were made less costly by employers: severance payments for new permanent contracts were cut from 30 to 20 days per year of tenure (capped at an employee's yearly wage), and then extended to all existing contracts. For fixed-term contracts, severance payments were also cut from a maximum of 36 to 20 days per year of service (Law 3/2012).

If the adjustment programme agreed with the Troika provided for a a considerable broadening of acceptable causes for dismissal, the actual reforms - negotiated with unions and employers - ended up going less far than its demands (Branco and Cardoso 2020, 10). As a whole, and keeping in mind the limitation of the aggregate indicators outlined above, in 2019 Portugal had moved from having formally the most restrictive employment protection legislation in Europe to fewer protections than the Netherlands, a country praised for its flexicurity model combining labour market flexibility and social protection (Oorschot 2004).

Minimum wages. The Portuguese minimum wage has been a structuring and ever more important instrument of regulation of the bottom end of the labour market. It was first set up in 1974 and has been set by the government. The clearest feature of the national minimum in the recent period has been the steady increase in the number of workers receiving the minimum wage over the last 20 years. In 2001, only $4 \%$ of dependent workers received the national minimum wage. In 2018 , this share had increased to $22 \%$, reaching $32 \%$ in restaurants, hotels and the tourism industry (Pordata 2020). This has resulted in a decline in wage inequality in the last 10 years as the minimum wages has increased at a faster pace than median salaries. In 2019, the Portuguese minimum wage was set at $61 \%$ of median wages, which was the highest percentage ex aequo with France, compared to $49 \%$ in Spain and $48 \%$ in Germany. In some way, this was a catching-up process as the minimum wage had increased at a lower rate than median wages up to the financial crisis, contributing to an increase in wage inequality. The 
minimum wage was frozen in nominal terms from 2011 to 2015 . The decrease in inequality was essentially a result of median wages decreasing to a greater extent in real terms.

Unemployment protection. Another feature of the Portuguese liberal employment regime has been the late and weak development of unemployment protection. While in Spain unemployment insurance coverage reached $70 \%$ of the workforce in 1980 , less than $10 \%$ of the Portuguese workforce could benefit from unemployment assistance in the same period. No unemployment insurance system existed before 1985 (Bover, García-Perea, and Portugal 2000, 386). Throughout the 1980s and 1990s, the share of the jobless effectively receiving unemployment benefits would consistently be higher in Spain than in Portugal, mostly due to more restrictive entitlement conditions. The first unemployment insurance system put in place in 1985 required employment for the whole of the previous 3 years to qualify; benefits amounted to $65 \%$ of the last salary. The equivalent in Spain required 6 months of employment in the previous 4 years, and benefits amounted to $80 \%$ of the last salary and decreasing to $60 \%$ after a year (Bover, García-Perea, and Portugal 2000, 423). As of the reform of 2006, unemployment benefits in Portugal were attributable to individuals who had worked a total of 450 days over a period of 2 years preceding the period of unemployment, and the replacement rate was set at 65\% (Decreto-Lei 220/2006, 2006-11-03 2006, 7695-96). In fact, according to a recent coding effort, the conditionality of unemployment benefits in Portugal has been the most restrictive in Europe (Knotz and Nelson 2019). This partly explains the low levels of coverage of unemployment benefits, namely the share of jobseekers who effectively receive some form of unemployment benefit: in 2016, this coverage amounted to amounted to $20 \%$ in Portugal (down from $34 \%$ in 2007) compared to $26 \%$ in Spain or 56\% in Belgium (OECD 2018, 194).

Here again, reforms were passed in the wake of the Eurozone crisis to accommodate the memorandum of understanding agreed with the Troika. These reforms sought to find a balance between cutting spending and maintaining or even expanding coverage. Hence, if the maximum amount o benefits was capped to a lower amount, the contribution requirement was relaxed to 720 days of work over a period of 4 years; coverage was extended to the self-employed and some benefits for specific groups were increased by 10\% (Branco and Cardoso 2020, 10; Decreto-Lei 65/2012, 2012-03-15 n.d., 1243). During the corona-crisis, an extensive furlough (layoff) scheme was put in place to support companies while protecting employment: the government paid $70 \%$ of workers' salaries in companies affected by the crisis on the condition they would retain their workforce (Lusa 2020). 


\section{Collective Bargaining and Industrial Relations}

Portugal is part of the universe of European countries where negotiations between employer associations and trade unions play a significant role in labour market regulation, wage-setting and working hours, but where it is also heavily supplemented by state intervention (Barreto and Naumann 1998; M. P. Campos Lima and Artiles 2011). Unlike Nordic countries where trade union density is high enough for trade unions to exert enough control on the labour market on their own, and unlike the United Kingdom or Eastern Europe where wages are mostly set by the market, in Portugal trade unions and employers bargain over wages and working conditions within economic sectors, and then the state has routinely extended the outcomes of these negotiations to whole sectors of the economy via so-called extension orders (portarias de extensao). This explains the wide discrepancy between the very low percentage of the workforce that is unionized (below 20\% in 2017) and the much higher degree of coverage of collective bargaining agreements (between 60\% and 90\%) (Addison, Portugal, and Vilares 2017; Visser 2019).

Collective bargaining coverage in Portugal has remained relatively stable over time despite a fairly dramatic decline in union density. From $60 \%$ of the workforce unionized in 1980, this share dropped to 30\% in 1990 and 15\% in 2017 (Visser 2019). Meanwhile, collective bargaining coverage has remained relatively stable mainly due to the systematic extension of collective bargaining agreement by the state through administrative orders. However, as outlined by Baccaro and Howell (2017), the persistence of institutions in form can conceal the actual functioning of wage-setting institutions.

In spite of this high level of state intervention and a high degree of coverage, the divisions within the left that characterised the transition to democracy in the 1970s have left an imprint where the level of wage protection provided to workers has been less extensive than in Spain. As outlined above, the control of the Communist party over the trade union movement and the largest trade union confederation, the CGTP, made the emergence of meaningful collaboration between state and unions difficult, and led centre-left and centre-right to seek to erode the communist grip on the labour movement. One of the mechanisms used to do this has been to rule out the establishment of any criterion of representativeness on the union side to engage in collective bargaining: all unions have equal rights and can engage in wage bargaining with employers independently of their size and representativeness. This was notably an instrument to allow the UGT, the trade union linked to the PS and the PSD, to gain a foothold in collective bargaining to the detriment of CGTP, allowing the UGT to sign agreements with 
public enterprises and the government (Barreto and Naumann 1998, 31). This situation was markedly different from Spain, where only unions large enough to receive $15 \%$ of votes in nationwide factory works council elections could negotiate collective labour agreements. In Portugal, this allowed employers to pick and chose smaller, more quiescent unions to negotiate wages while Spanish employers could not. This led to lower wages in Portugal especially at the bottom of the labour market, as well as greater wage dispersion and inequality than in Spain (Watson 2015, 5-6). In 2004, income inequality was greater in Portugal than in any other EU country, including the United Kingdom (OECD 2020a). In 2003 and 2009, reforms of the collective bargaining framework allowed for further flexibility, notably by allowing collective agreements to depart in pejus - offering less favourable terms for employees - from statutory regulations and allowing negotiating parties to unilaterally request the expiry of collective agreements (M. Campos Lima 2020, 485).

In the 2010s, amidst the Eurozone crisis, the Portuguese architecture of collective bargaining came again under pressure. Seen as entailing too much nominal wage rigidity, the Troika and external lenders recommended its decentralisation by leaving more room for company agreements while these tended to play a marginal role in wage setting (Addison, Portugal, and Vilares 2017, 3; Bulfone and Afonso 2020). Similarly, the system of extension orders was perceived to slow down wage adjustment in a time of high unemployment, and impose high costs on parties that did not negotiate the agreements in the first place (Martins 2020). In the absence of representativeness requirements, wage agreements negotiated by employers and unions representing only a small share of the workforce in a given sector would routinely be extended to the whole sector. Because companies who negotiate agreements tend to have higher wages, they impose wage floors on companies who cannot practice the same wage levels, with losses of employment. Besides, it was also the case that collective agreements would remain in place as long as no change was agreed on between negotiating parties, in order to avoid contacts expiring and workers being left uncovered.

In 2012 the centre-right government of Pedro Passos Coelho adopted new rules for the extension of collective labour agreements, requiring that they could only be extended if the signing parties represented more than half of the workforce in any given sector (Addison, Portugal, and Vilares 2017, 7; Bulfone and Afonso 2020). Moreover, new rules were adopted allowing the actual expiry of collective labour agreements, opening the possibility for a decline in coverage. 
Given the level of fragmentation of union and employer organisations, the new requirements for extension was a fairly high bar and it effectively led collective bargaining to come to a standstill. In effect, the introduction of these more restrictive rules, combined with the crisis, led to a significant decrease in the number of extension orders being issued, but also in the number of collective agreements being renewed and renegotiated, falling from 251 covering 1.4 million workers in 2009 to 94 covering 242'000 workers in 2013 (UGT 2020, 3-4). This decrease was due to employers and unions not meeting the requirements for extension, but above all to employers simply not engaging in wage negotiations, as they knew that if the quota was not met, their competitors would not have to comply with the same terms (Bulfone and Afonso 2020). This dis not lead to a decline in coverage, however. These changes were resisted by both unions and employer associations who had an interest in the persistence of compulsory wage floors that could discipline their low-wage competitors. Effectively, rules were altered again in 2014 to loosen the requirements for extension, and the number of agreements being negotiated went back to its pre-crisis levels; total coverage remained stable (Addison, Portugal, and Vilares 2017). The resilience in the coverage of collective agreements did not preclude a significant level of downward wage adjustment in the wake of the eurocrisis. In 2011 and 2012, nominal wage increases stayed below inflation, resulting in a decrease in real wages, and stayed below 1\% between 2013 and 2015 (UGT 2020, 8).

\section{Labour Market Outcomes}

While Portuguese labour market policies display many commonalities with other Southern European countries, labour market outcomes have shown some specificities when it comes to female employment, unemployment, and inequality.

One of the most distinctive features of the Portuguese labour market has been the high participation rate of women. In 2019, the employment rate - the share of people 20 to 64 who hold a job - for women in Portugal was $72.7 \%$, compared to an average of $67.3 \%$ in the EU27, $62 \%$ in Spain, and $53.8 \%$ and $51.3 \%$ in Italy and Greece respectively. ${ }^{1}$ Figure 1 shows the

\footnotetext{
${ }^{1}$ If we take full-time equivalents, Portuguese women have one of the highest employment rates in Europe because very few of them work part-time: the full-time equivalent employment rate for women in Portugal was $61 \%$, compared to an average of $53.2 \%$ across the OECD, $44 \%$ in the Netherlands and $55 \%$ in Denmark.
} 
female employment/population ratio for Portugal and other selected European countries between 1960 and 2018, showing the distinctive trajectory of female employment in Portugal compared to the rest of Southern Europe: numbers have been more on par with Germany than Italy, Spain or Greece in spite of the absence of progressive gender norms or labour market institutions that have been believed to foster female employment (Cardoso and Morin 2018; Tavora 2012).

Figure 1: Female employment/population ratio in selected countries, 15-64

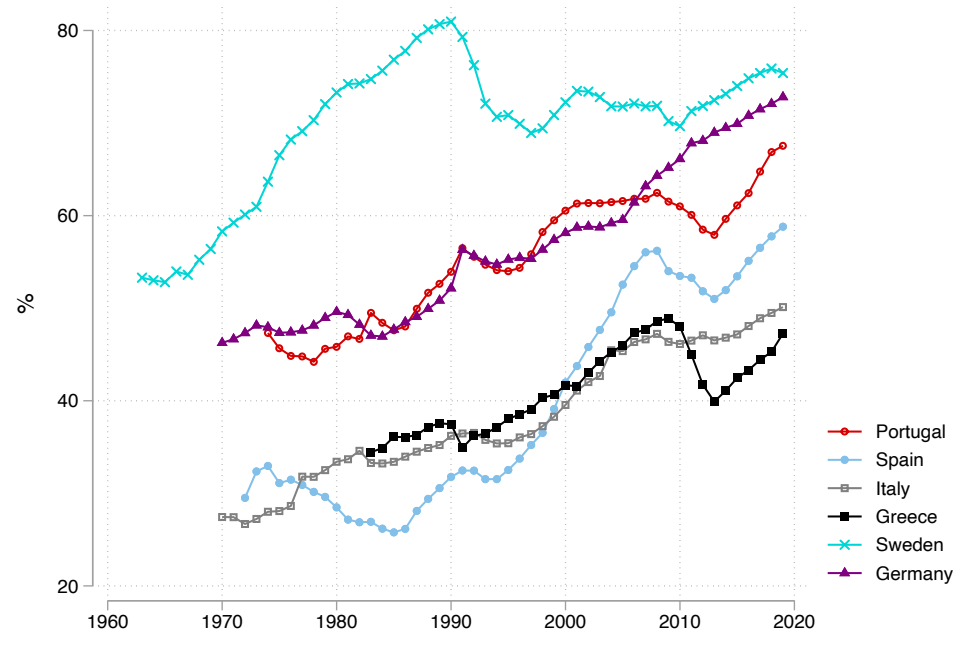

Source: OECD Labour Force Statistics

This pattern started in the 1960s. Between 1960 and 1981, the number of employed men in the Portuguese workforce decreased by $112^{\prime} 000$ individuals, while the number of employed women increased by $871^{\prime} 000$. The share of women in the workforce doubled from 17 to $34 \%$ during that period. The female labor force participation has been high ever since. While the size of the male workforce was smaller in 2011 than in 1960, the size of the female workforce quadrupled.

Four factors have been believed to have shaped this pattern and its take-off in the 1960s. The first was the colonial war (1961-1974) and the mobilization of a large number of young men away from the labour force. The second was emigration. Between 1961 and 1973, approximately 1.6 million individuals left the country, or $18 \%$ of the 1960 population. Emigration tended to involve, at least in the beginning, a disproportionate share of men. Cardoso and Morin $(2018,19)$ find that approximately 8 to $12 \%$ of the Portuguese male age 
cohorts born in the 1940s were living in Germany or France in the early 1970s. Both factors created a labour shortage that created a large demand for female labour. Third, the expansion of a number of industries offering job opportunities for women, textile in particular, also facilitated the feminization of the workforce (André 2002). Fourth, lower wage levels than elsewhere in Southern Europe have also made double income households more than elsewhere an economic necessity. Unlike continental countries with a high female employment rate, such as the Netherlands (Afonso and Visser 2014), part-time work among women is not widespread. Only $9.6 \%$ of Portuguese women worked part-time in 2018 , compared to $58 \%$ in the Netherlands. In fact, Portuguese married women worked the largest number of hours of all countries analysed by Bick et al. (2019, 45). Portuguese childcare facilities appear more supportive for employment than in other comparable Southern European countries, especially for low income families (Tavora 2012, 102).

The second notable feature has been comparatively low unemployment levels and high employment rates especially for individuals with lower education levels. In Portugal, the employment rate for people with below-upper secondary education was $70.3 \%$ in 2018 , compared to an average of 59\% across OECD countries. It must be noted that Portugal is also an outlier in Europe with regard to the proportion of the population with that education level: $47 \%$ of the population $25-64$ had below upper-secondary education, compared to $21 \%$ across the OECD. Overall, the Portuguese workforce is significantly less qualified on average than other European countries, even if things are changing. Unemployment, for its part, has also been much lower than in Spain, notably because of the more liberal features of its labour market institutions (less generous unemployment protection, wage-setting institutions favouring wage restraint) that favoured employment at the cost of higher inequality and poverty.

The last feature worth analysing is the pattern of income inequality. As argued above, the political power relationship that came out of the transition to democracy favoured an employment regime favouring the expansion of low-skilled employment, resulting in lower unemployment than in Spain, but at the cost of higher inequality and poverty. Between 1980 and 2000, these choices led to a distinct increase in income inequality: the income share of the top $10 \%$ increased from $30 \%$ of the national income to $40 \%$ in 2000 , and was higher than any other country in Southern Europe. During the same period, income inequality in Spain tended to decrease. In 2011, Portugal had one of the most unequal market income distributions in Europe, and poverty rates were high (Arnold and Rodrigues 2015, 5). One of the possible underlying factors of this high level of inequality is the education profile of the population, characterized for a long time by a very low proportion of graduates of tertiary education, leading to higher 
wage returns to education. Indeed, the wage premium for reaching higher education in Portugal was the highest in Europe, namely a $98 \%$ premium compared to $43 \%$ across the European Union (Badescu, D’Hombres, and Villalba 2011, 21).

In 2017, the Gini index for the working-age population was higher than the United Kingdom, but it had somehow declined since the financial crisis. This was mostly a result of the decline in median wages that followed the Eurozone crisis, whereas wages at the bottom were protected to some extent. Austerity reforms carried out with the objective of fiscal consolidation also tended to target high-income households to a greater extent than in Spain or Greece, where inequality increased (Avram et al. 2013)

Hence, while the Portuguese labour market was traditionally characterized by higher levels of income inequality than comparable countries up to the early 2000 s, it seems to have converged in recent years.

\section{Conclusion}

In this chapter, I have outlined the main characteristics of the Portuguese employment regime with regard to public policies, collective-bargaining and wage setting, as well as labour market outcomes. I have shown that while Portuguese labour market institutions share many characteristics with other southern European economies, employment performance has also displayed very specific characteristics that led to a level of overperformance with respect to the model on a number of indicators. This has notably been the case in the domain of employment rates for specific groups of the labour market, most notably women and the low skilled. These high employment levels have come at the cost of relatively high levels of inequality which have tended to decline in recent years.

There are a number of avenues for further research which could shed light on the specificities of the Portuguese employment regime. The first would be a deeper understanding of the interplay between institutions and values that explain the high employment rate of Portuguese women. Portugal is clearly an outlier in southern Europe, achieving employment rates more on par with North European countries without the supporting institutions or more egalitarian gender norms found in these countries. The fact that part-time employment is weakly used is one further puzzling pattern that would need to be explained, and the role of informal support and how it may enable labour force participation to a greater extent than in comparable countries would need to be explored. Second, from a political science perspective, an important avenue for research would be to analyse the extent to which the labour market features have 
shaped political attitudes. Traditionally, class has been believed to play only a small role in political preferences in the Portuguese context (Magalhães 2005), but developments such as technological change or globalization have been said to lead to significant political changes in advanced industrialised countries (Kitschelt and Rehm 2014). This remains to be done in the Portuguese context. Finally, an important feature of Portuguese society and labour market has been emigration, but its precise implications for labour market governance have remained relatively unexplored. For instance, high levels of emigration may have worked as safety valves for unemployment by "exporting" some if of the low-skilled workforce. The extent to which these hypotheses are supported empirically still needs to be assessed.

\section{References}

Addison, John T., Pedro Portugal, and Hugo Vilares. 2017. "Unions and Collective Bargaining in the Wake of the Great Recession: Evidence from Portugal." British Journal of Industrial Relations 55(3): 551-76. https://onlinelibrary.wiley.com/doi/abs/10.1111/bjir.12198 (December 4, 2020).

Afonso, Alexandre. 2019. "State-Led Wage Devaluation in Southern Europe in the Wake of the Eurozone Crisis." European Journal of Political Research 58(3): 938-59. https://ejpr.onlinelibrary.wiley.com/doi/abs/10.1111/1475-6765.12317 (October 1, 2020).

Afonso, Alexandre, and Jelle Visser. 2014. "The Liberal Road to High Employment and Low Inequality? The Dutch and Swiss Social Models in the Crisis." In European Social Models From Crisis to Crisis: Employment and Inequality in the Era of Monetary Integration, Oxford: Oxford University Press. https://oxforduniversitypressscholarshipcom.ezproxy.leidenuniv.nl:2443/view/10.1093/acprof:oso/9780198717966.001.0001/ac prof-9780198717966-chapter-7 (December 9, 2020).

Amaral, Luciano. 2010. Economia Portuguesa: As Ultimas Décadas. Lisbon: Fundaçao Francisco Manuel dos Santos.

André, Isabel Margarida. 2002. "At the Centre on the Periphery? Women in the Portuguese Labour Market." In Women of the European Union, Routledge, 153-170.

Arnold, Jens, and Carlos Farinha Rodrigues. 2015. "Reducing Inequality and Poverty in Portugal." https://www.oecd-ilibrary.org/economics/reducing-inequality-and-povertyin-portugal_5jrw21ng3ts3-en (December 9, 2020).

Avram, Silvia et al. 2013. "The Distributional Effects of Fiscal Consolidation in Nine Countries.” EUROMOD Working Paper Series: EM2/13.

Baccaro, Professor Lucio, and Professor Chris Howell. 2017. Trajectories of Neoliberal Transformation: European Industrial Relations Since the 1970s. Cambridge, United Kingdom New York NY, Port Melbourne: Cambridge University Press. 
Badescu, Mircea, Béatrice D'Hombres, and Ernesto Villalba. 2011. Returns to Education in European Countries-Evidence from the European Community Statistics on Income and Living Conditions (EU-SILC). European Commission. https://op.europa.eu/en/publication-detail/-/publication/eb52035f-de35-4d43-8430fcc10a9ff1c9/language-en.

Baklanoff, Eric N. 1992. “The Political Economy of Portugal's Later 'Estado Novo': A Critique of the Stagnation Thesis." Luso-Brazilian Review 29(1): 1-17. https://www.jstor.org/stable/3513163 (January 21, 2020).

Barreto, José, and Reinhard Naumann. 1998. "Portugal: Industrial Relations under Democracy." Changing industrial relations in Europe: 395-425.

Bick, Alexander, Bettina Brüggemann, Nicola Fuchs-Schündeln, and Hannah PaulePaludkiewicz. 2019. "Long-Term Changes in Married Couples' Labor Supply and Taxes: Evidence from the US and Europe since the 1980s." Journal of International Economics 118: 44-62.

http://www.sciencedirect.com/science/article/pii/S0022199618302812 (December 9, 2020).

Bover, Olympia, Pilar García-Perea, and Pedro Portugal. 2000. "Labour Market Outliers: Lessons from Portugal and Spain." Economic Policy 15(31): 380-428. https://academicoup-com.ezproxy.leidenuniv.nl:2443/economicpolicy/article/15/31/380/2366378 (December 1, 2020).

Branco, Rui, and Daniel Cardoso. 2020. "The Politics of Change. Coalitional Politics and Labour Market Reforms during the Sovereign Debt Crisis in Portugal." Journal of Social Policy: 1-19. https://www.cambridge.org/core/journals/journal-of-socialpolicy/article/abs/politics-of-change-coalitional-politics-and-labour-market-reformsduring-the-sovereign-debt-crisis-inportugal/DD4F6A2A6059F63475A1159E4E5BE31C (December 2, 2020).

Bulfone, Fabio, and Alexandre Afonso. 2020. "Business Against Markets: Employer Resistance to Collective Bargaining Liberalization During the Eurozone Crisis." Comparative Political Studies 53(5): 809-46. https://doi.org/10.1177/0010414019879963 (April 7, 2020).

Campos Lima, M. 2020. "Portugal: Reforms and the Turn to Neoliberal Austerity." In Collective Bargaining in Europe: Towards an Endgame., eds. Torsten Muller, Kurt Vandaele, and Jeremy Waddington. ETUI, 483-504. https://www.etui.org/publications/books/collective-bargaining-in-europe-towards-anendgame-volume-i-ii-iii-and-iv.

Campos Lima, M. P., and A. M. Artiles. 2011. "Crisis and Trade Union Challenges in Portugal and Spain: Between General Strikes and Social Pacts." Transfer: European Review of Labour and Research 17: 387-402.

Cardoso, Ana Rute, and Louis-Philippe Morin. 2018. Can Economic Pressure Overcome Social Norms? The Case of Female Labor Force Participation. IZA Discussion Papers. Working Paper. https://www.econstor.eu/handle/10419/185282 (December 8, 2020).

Crouch, Colin. 1993. Industrial Relations and European State Traditions. Oxford: Clarendon Press. 
“Decreto-Lei 65/2012, 2012-03-15.” Diário da República Eletrónico. https://dre.pt/pesquisa//search/553471/details/normal?q=DecretoLei+n.\%C2\%BA\%2065\%2F2012\%2C\%20de+15+de+mar\%C3\%A7o (December 3, 2020).

Decreto-Lei 220/2006, 2006-11-03. 2006. https://dre.pt/pesquisa//search/546202/details/maximized (December 3, 2020).

Esping-Andersen, Gøsta. 1990. The Three Worlds of Welfare Capitalism. Cambridge: Polity Press.

Ferrera, M. 1996. “The'southern Model'of Welfare in Social Europe.” Journal of European social policy 6: 17-37.

Hall, Peter A., and David W. Soskice. 2001. Varieties of Capitalism : The Institutional Foundations of Comparative Advantage. Oxford: Oxford University Press.

ILO. 2019. A OIT e Portugal: 100 Anos de Historia. Geneva: ILO.

Kitschelt, Herbert, and Philipp Rehm. 2014. "Occupations as a Site of Political Preference Formation." Comparative Political Studies 47(12): 1670-1706. https://doi.org/10.1177/0010414013516066 (December 10, 2018).

Knotz, Carlo Michael, and Moira Nelson. 2019. "The Comparative Unemployment Benefit Conditions \& Sanctions Dataset."

https://dataverse.harvard.edu/dataset.xhtml?persistentId=doi:10.7910/DVN/HZCUTC (December 3, 2020).

Korpi, W. 1983. The Democratic Class Struggle. London: Routledge \& Kegan Paul Books.

Lusa, PÚBLICO. 2020. “'Layoff': regime normal dá direito a complemento e o simplificado pode ir até Setembro." PÚBLICO. https://www.publico.pt/2020/06/25/economia/noticia/layoff-regime-normal-direitocomplemento-simplificado-ir-ate-setembro-1921851 (December 14, 2020).

Magalhães, Pedro C. 2005. "Disaffected Democrats: Political Attitudes and Political Action in Portugal." West European Politics 28(5): 973-91. https://doi.org/10.1080/01402380500310626 (January 4, 2019).

Martins, Pedro S. 2020. “30,000 Minimum Wages: The Economic Effects of Collective Bargaining Extensions." British Journal of Industrial Relations n/a(n/a). https://onlinelibrary.wiley.com/doi/abs/10.1111/bjir.12564 (December 5, 2020).

Moury, Catherine, and Adam Standring. 2017. "“Going beyond the Troika': Power and Discourse in Portuguese Austerity Politics." European Journal of Political Research 56(3): 660-79. http://onlinelibrary.wiley.com/doi/abs/10.1111/1475-6765.12190 (June $9,2019)$.

OECD. 2018. OECD Employment Outlook 2018. Paris: OECD Publishing Paris.

_. 2020a. "Inequality - Income Inequality - OECD Data." theOECD. http://data.oecd.org/inequality/income-inequality.htm (December 4, 2020). 
2020b. "OECD Labour Force Statistics." https://www.oecd-

ilibrary.org/employment/oecd-labour-force-statistics_23083387 (December 15, 2020).

Oorschot, Wim van. 2004. "Balancing Work and Welfare: Activation and Flexicurity Policies in The Netherlands, 1980-2000." International Journal of Social Welfare 13(1): 15-27. https://onlinelibrary.wiley.com/doi/abs/10.1111/j.1369-6866.2004.00294.x (December $2,2020)$.

Perez, Sofia A., and Manos Matsaganis. 2019. "Export or Perish: Can Internal Devaluation Create Enough Good Jobs in Southern Europe?" South European Society and Politics 24(2): 259-85. https://doi.org/10.1080/13608746.2019.1644813 (November 24, 2020).

Pordata. 2020. "Salário Mínimo Nacional." https://www.pordata.pt/Portugal/Sal\%c3\%a1rio+m\%c3\%adnimo+nacional-74 (December 14, 2020).

Regini, Marino, Emmanuele Pavolini, and Luigi Burroni. 2021. Mediterranean Capitalism Revisited. Ithaca: Cornell University Press.

Tavora, Isabel. 2012. "Understanding the High Rates of Employment among Low-Educated Women in Portugal: A Comparatively Oriented Case Study." Gender, Work \& Organization 19(2): 93-118. http://onlinelibrary.wiley.com/doi/abs/10.1111/j.14680432.2010.00489.x (April 7, 2020).

UGT. 2020. Relatório Negociação Colectiva 2020. Lisbon: UGT. https://www.ugt.pt/comunicados/comunicados-741?ano=2020\&tipo $=($ December 7 , 2020).

Visser, Jelle. 2019. "ICTWSS Database.” https://www.ictwss.org/downloads (December 4, 2020).

Watson, Sara. 2015. The Left Divided: The Development and Transformation of Advanced Welfare States. Oxford, New York: Oxford University Press.

Zartaloudis, Sotirios, and Andreas Kornelakis. 2017. "Flexicurity between Europeanization and Varieties of Capitalism? A Comparative Analysis of Employment Protection Reforms in Portugal and Greece." JCMS: Journal of Common Market Studies 55(5): 1144-61. https://onlinelibrary.wiley.com/doi/abs/10.1111/jcms.12533 (April 2, 2020). 
Figure 1: Minimum wage vs. base median wage and income

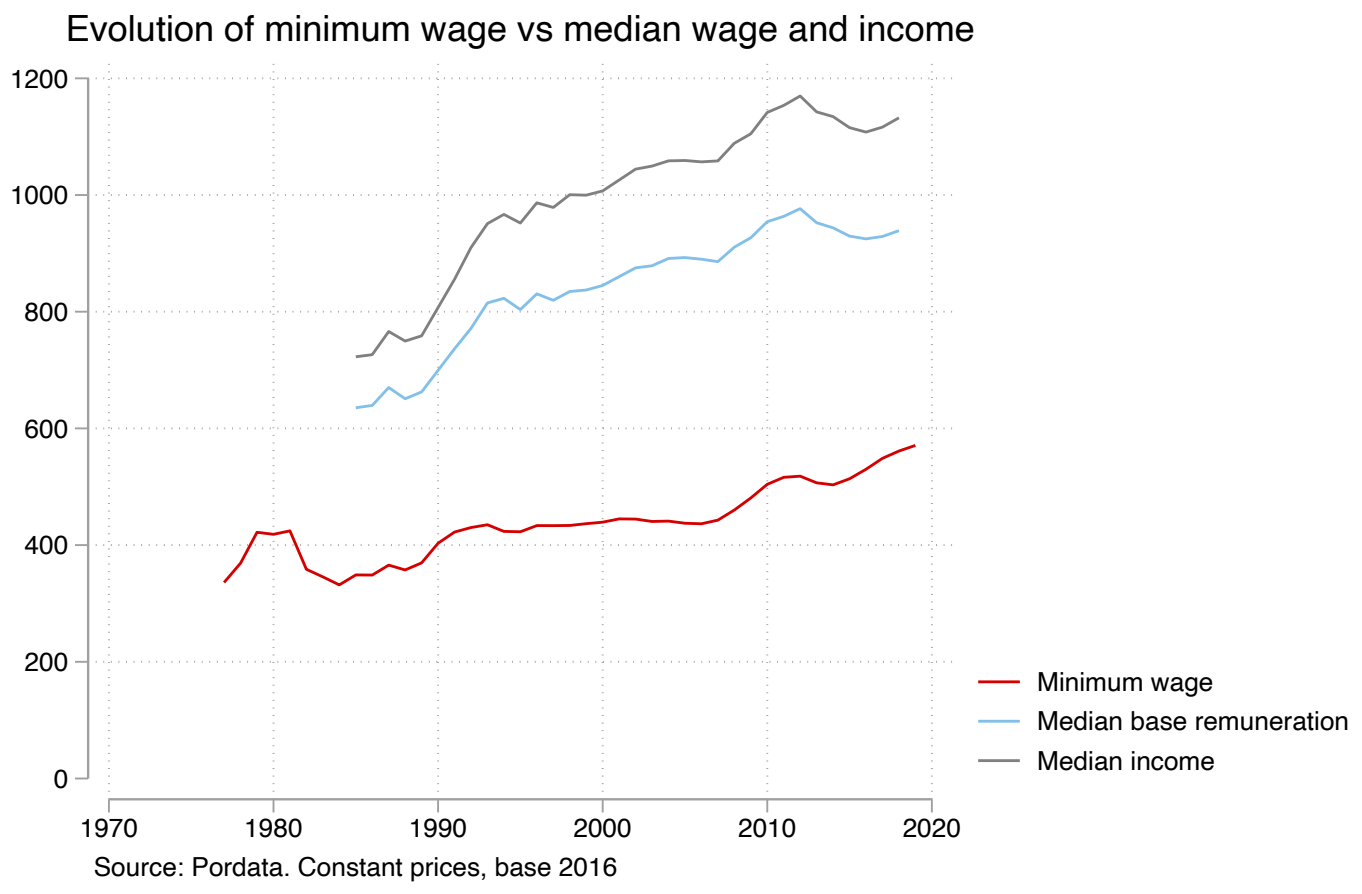

Figure 2: OECD Employment Protection legislation Index, 1990-2018

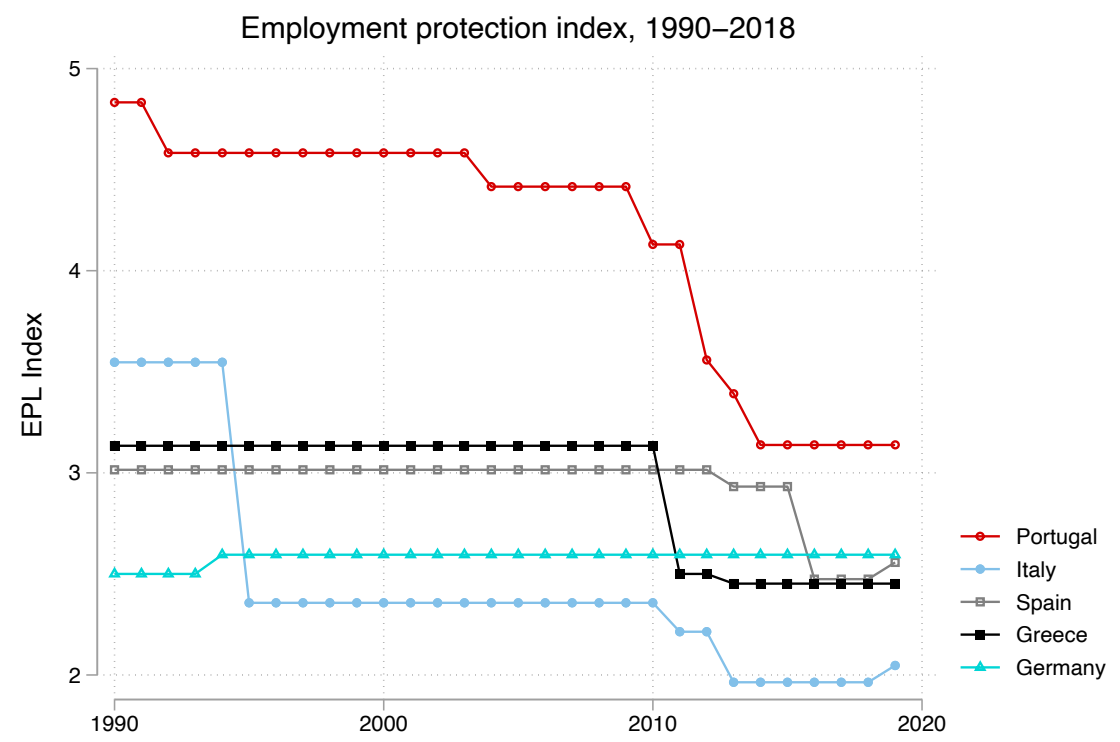


Figure 3: Union density and bargaining coverage (adjusted) in Southern Europe, 1960-2018

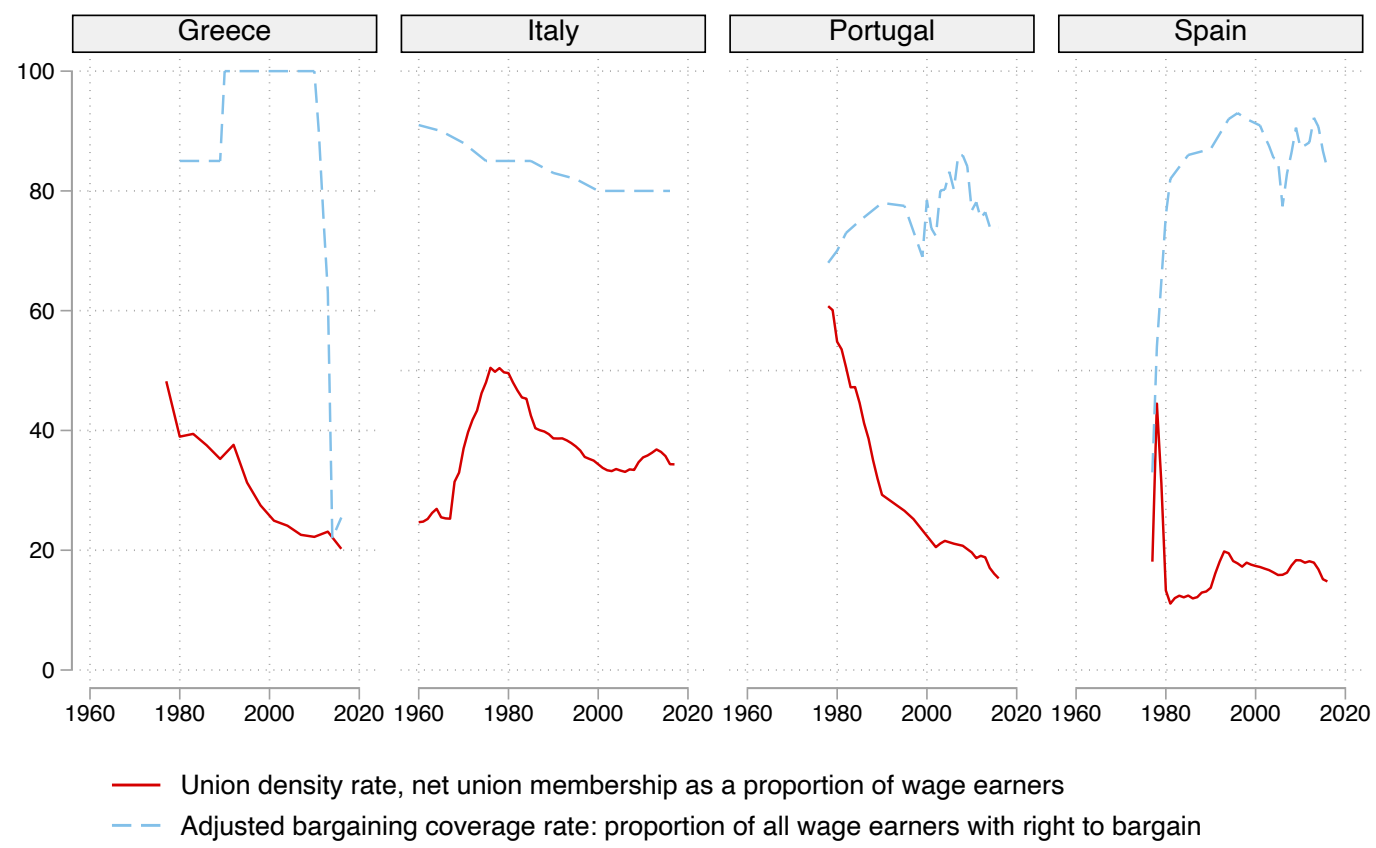

Source: ICTWSS database

Figure 4: Harmonised unemployment rate in Southern Europe, 1980-2019

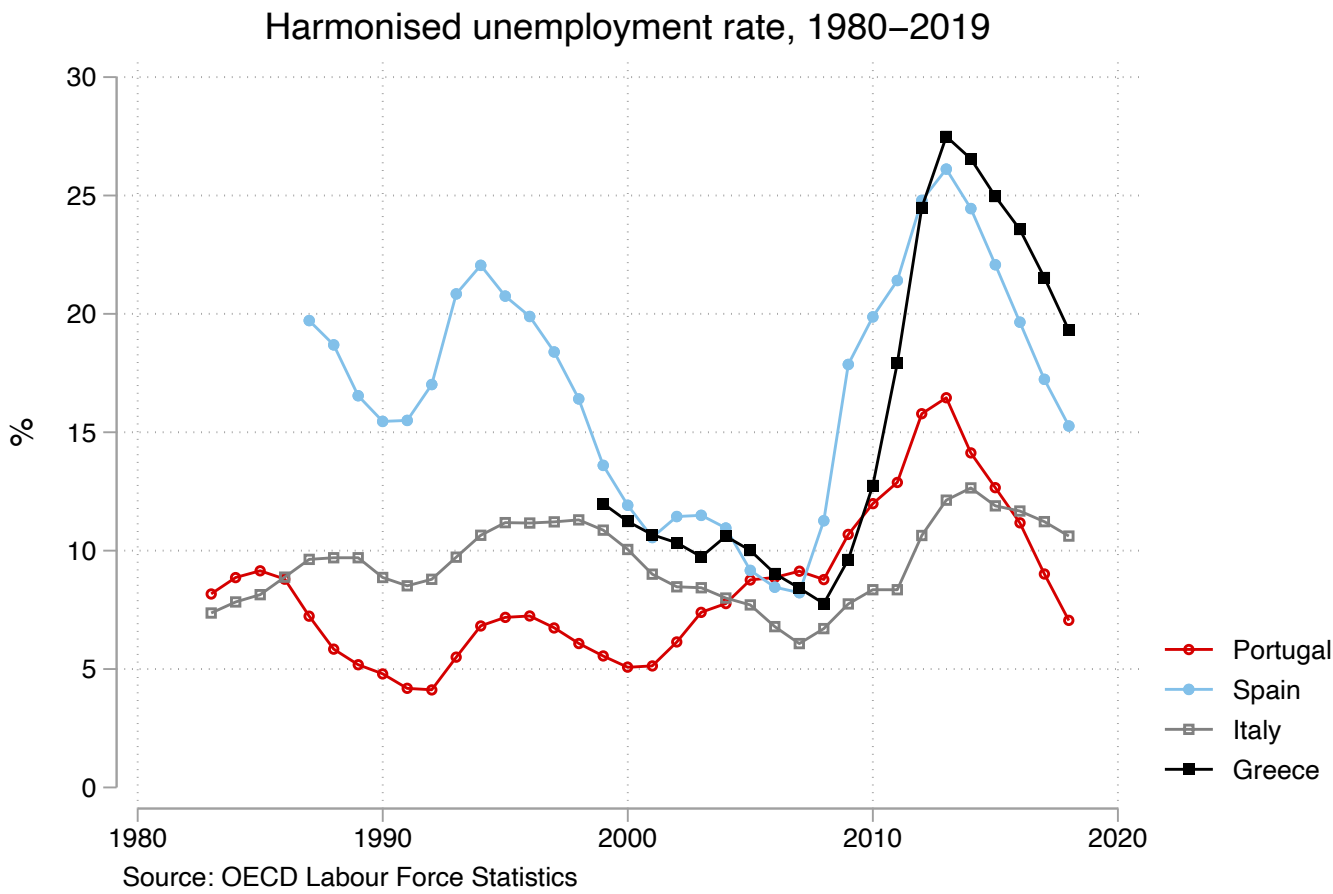


Figure 5: Share of men and women in the labour force in Souther Europe, 1980-2019

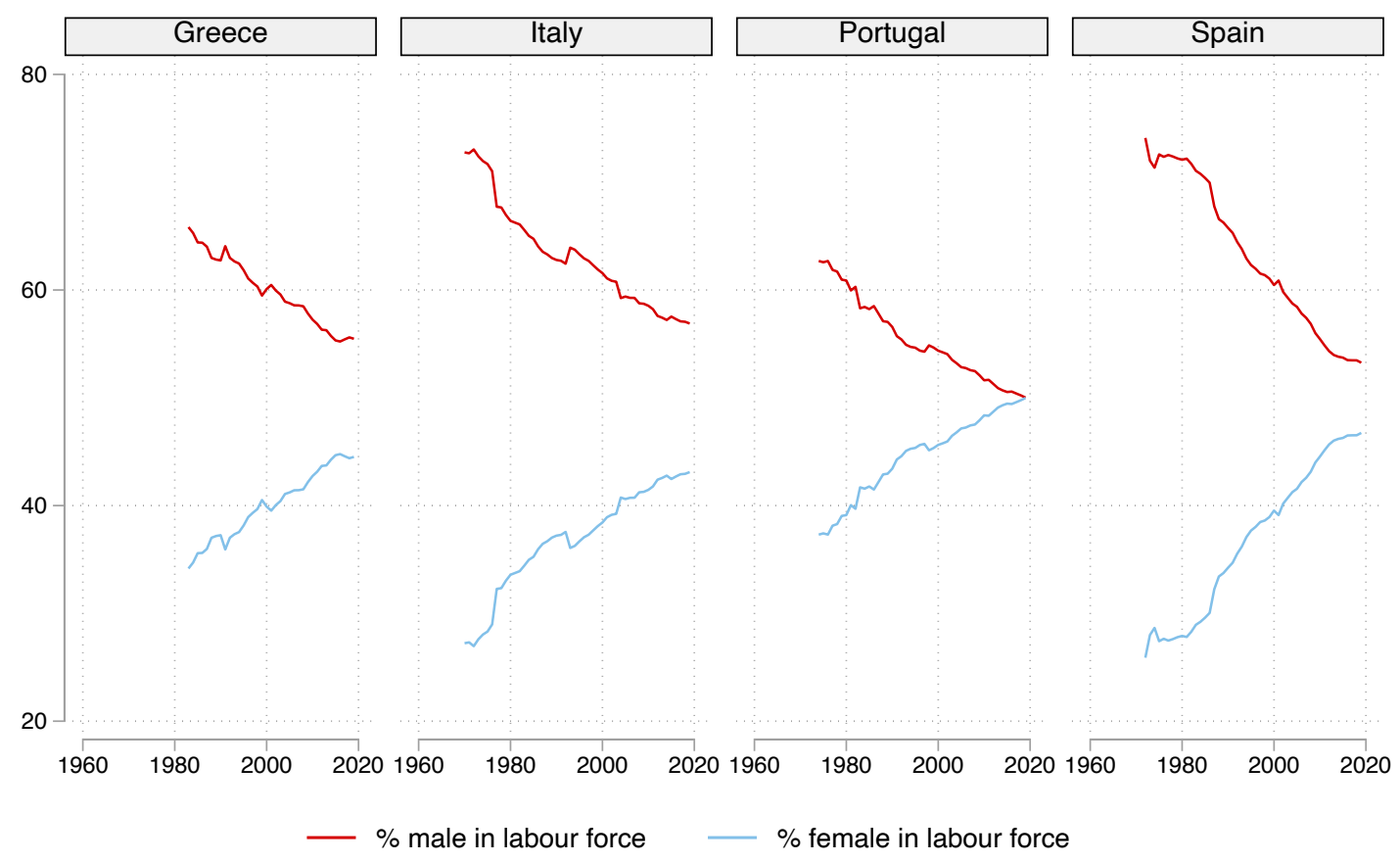

Source: OECD Labour Force Statistics

Figure 6: Employed persons according to the census by gender, 1960-2011

Employed persons by gender according to the census, 1960-2011

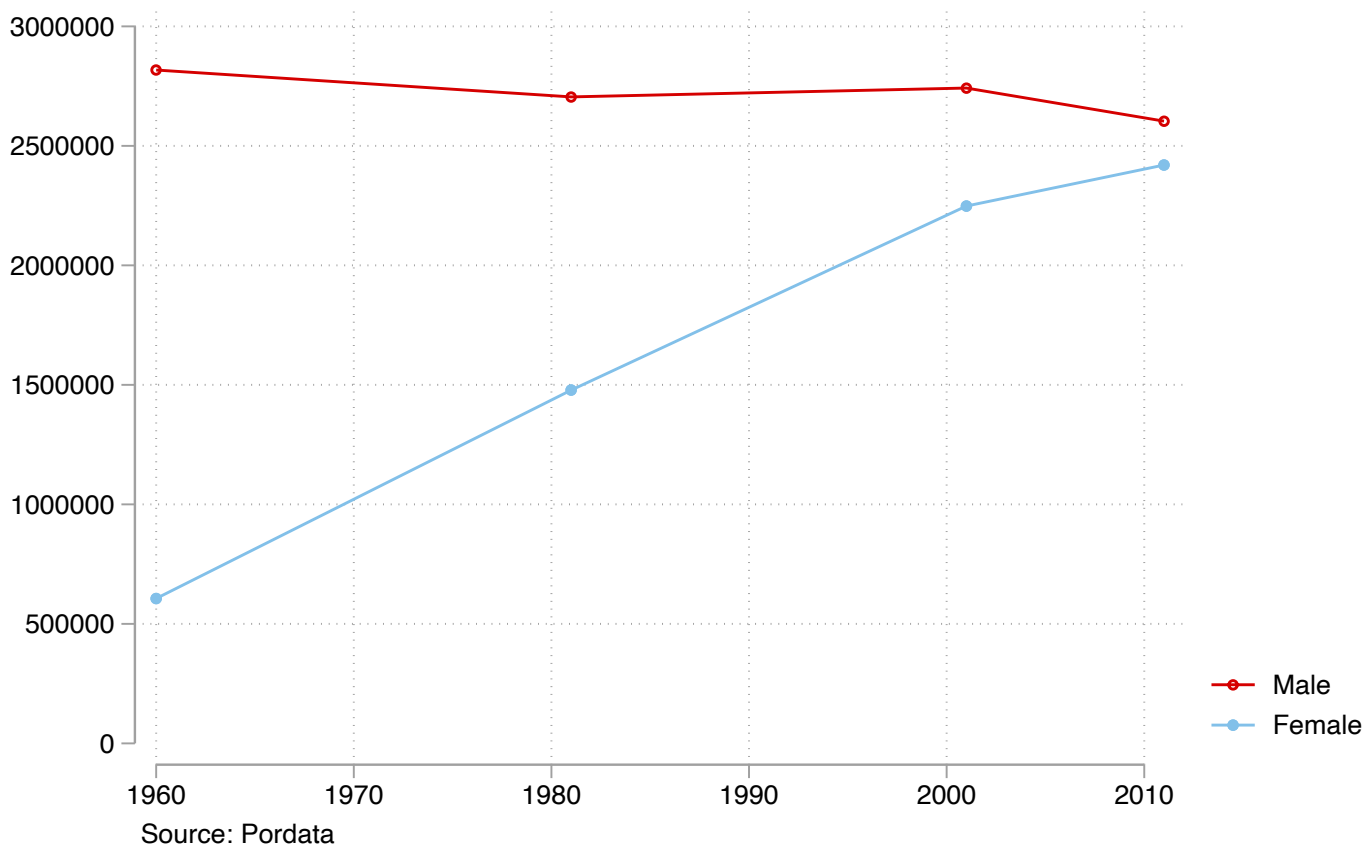


Figure 7: Female employment rate (Full-time equivalent), 2018

Female employment rate (full-time equivalent), 2018

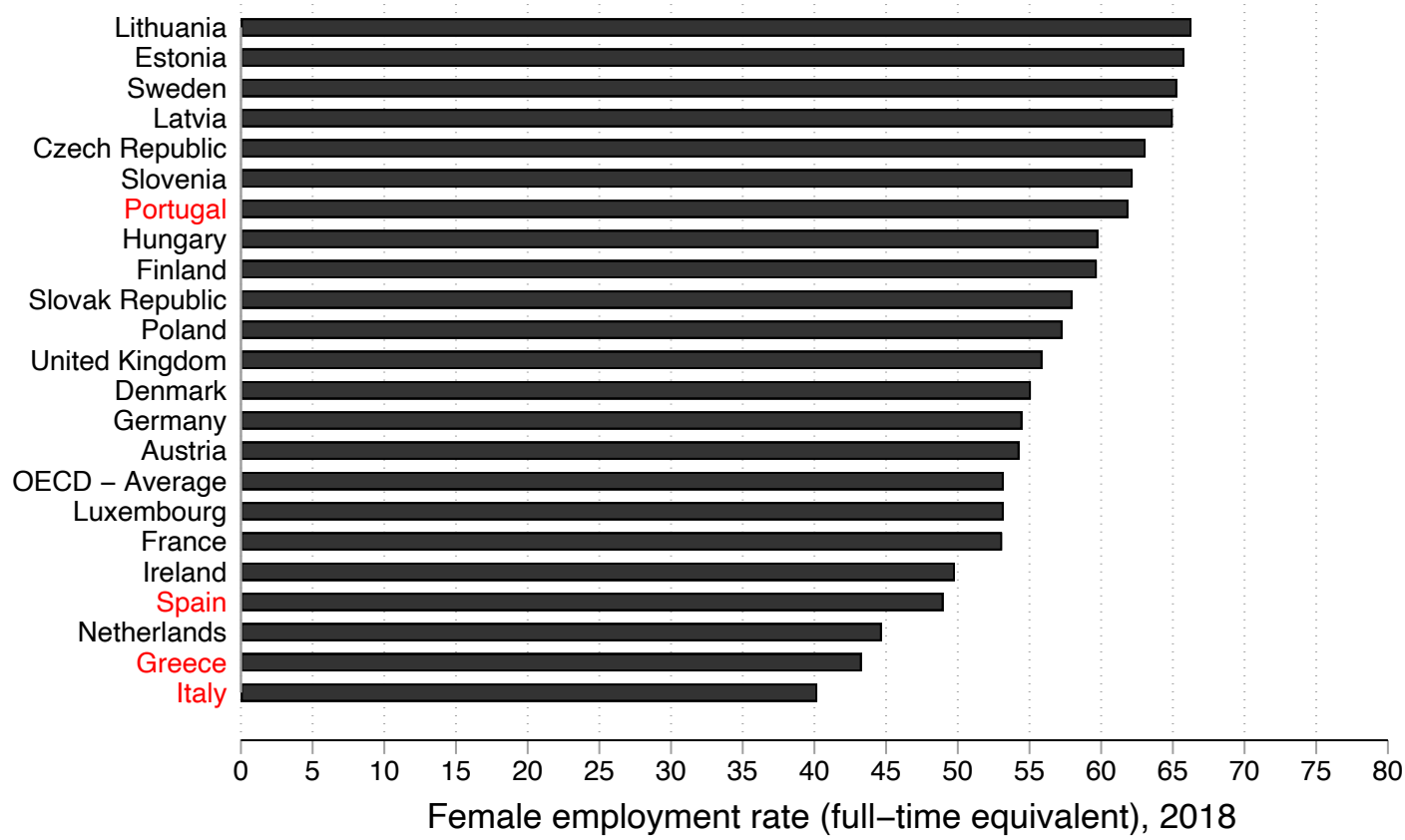

Figure 8: Income share of top 10\% and bottom 50\%, 1980-2019

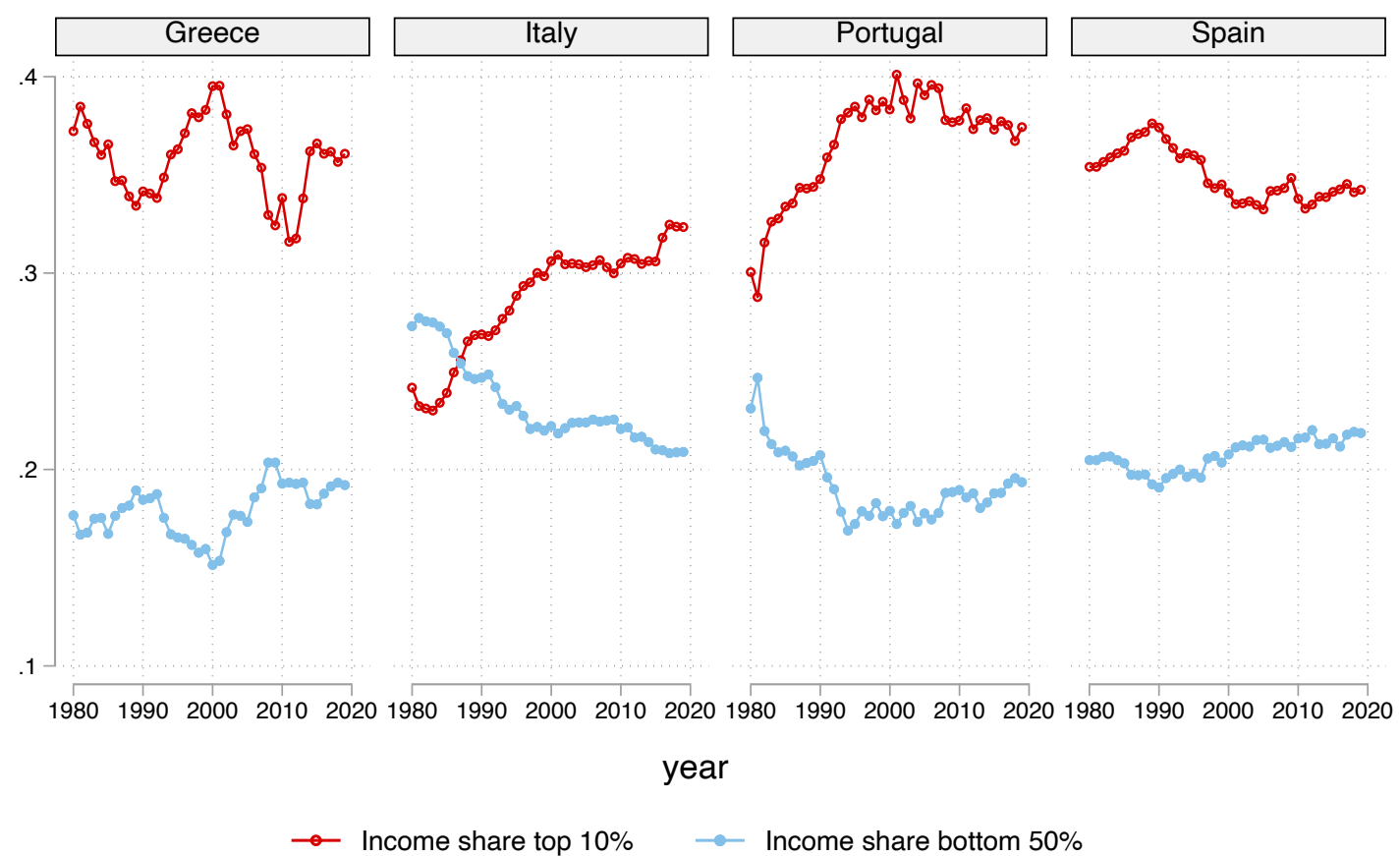

Source: World inequality database 
Figure 9: Gini index for working age population, 2000-2017

Gini Index, working age population, 2005-2019

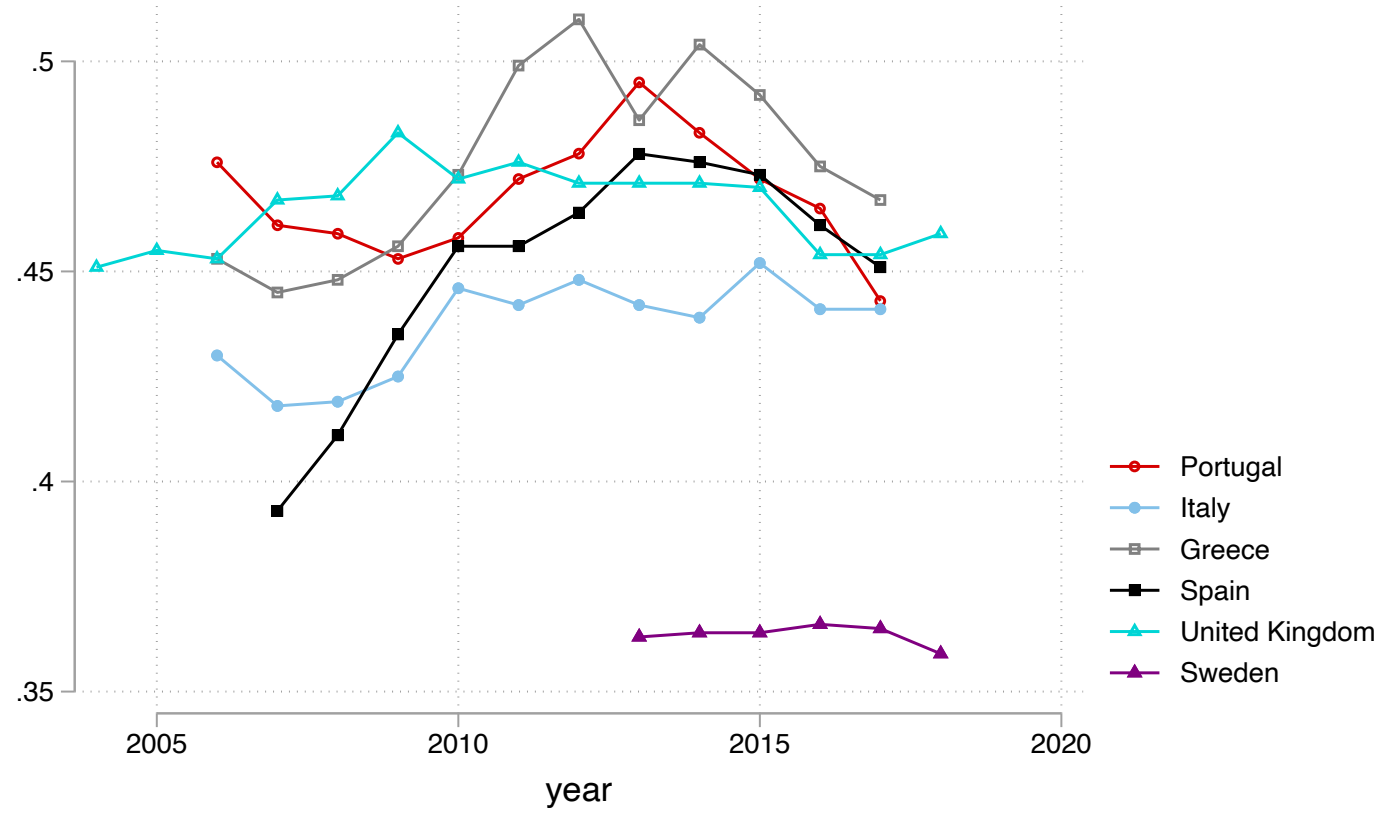

Source: OECD Labor force statistics 